\title{
Perilaku Geser Tanah yang Distabilisasi dengan Abu Ampas Tebu- Semen dan Inklusi Serat Polyester
}

\author{
"John Tri Hatmoko, Hendra Suryadharma \\ Program Studi Teknik Sipil Universitas Atma Jaya Yogyakarta \\ *) john@mail.uajy.ac .id
}

Received: 15 September 2017 Revised: 4 Oktober 2017 Accepted: 13 Oktober 2017

\begin{abstract}
A set of experiment programs were done to investigate the randomly oriented polyester fibre inclusion in bagasse ash-cement stabilized soil. Bagasse ash was mixed with clay in different proportions. To get the optimum curing period, it was done light compaction test of soil with 8\% cement cured with 7, 14, 21, 28 and 36 days curing period, that was found on 28 days. The next experiment was compaction test on soil $+8 \%$ cement + 3, 6, 9 and 12\% bagasse ash to obtain optimum bagasse ash proportion. The result indicated that optimum bagasse ash content was $9 \%$. To ensure this result, unconfined compression test was done on the same sample. Finally, light compaction, unconfined compression and direct shear tests were done on: soil $+8 \%$ cement $+9 \%$ bagasse ash + polyester fibre with 28 days curing period. The results showed that maximum dry density and optimum moisture content was not influenced by fibre inclusion, whereas the increase of shear strength of stabilized soil with fibre inclusion was mainly due to improvement of internal friction angle. In unconfined compression test, the unconfined compression strength of stabilized soil was significantly improved by fibre inclusion.
\end{abstract}

Key words: Bagasse ash, cement, soil, polyester fibre

\begin{abstract}
Abstrak
Serangkaian pengujian dilakukan untuk meneliti pengaruh serat polyester dengan orientasi bebas pada perilaku geser tanah yang distabilisasi dengan abu ampas tebu (AAT) dan semen. AAT dicampur dengan tanah lempung dengan proporsi yang bervariasi. Untuk mengetahui masa pemeraman optimal, dilakukan uji pemadatan ringan dengan kadar semen $8 \%$. Pada pengujian ini tanah $+8 \%$ semen dipadatkan dan diperam dalam waktu 7, 14,21,28 dan 36 hari dan diperoleh kepadatan kering maksimum pada waktu peram 28 hari. Kemudian dilakukan uji pemadatan tanah + 8\% semen + AAT dengan proporsi 3, 6, 9 dan 12\% untuk memperoleh kadar AAT optimum. Pada pengujian tersebut diperoleh kadar AAT optimum sebesar $9 \%$. Sampel yang sama diuji didalam uji tekan bebas dan diperoleh kadar AAT optimal yang sama. Komposisi terakhir: tanah $+8 \%$ semen $+9 \%$ AAT + serat polyester waktu peram 28 hari diuji pemadatan, tekan bebas dan geser langsung. Hasil pengujian pemadatan diperoleh bahwa kepadatan maksimm dan kadar air optimum tidak banyak terpengaruh oleh tulangan serat. Dari pengujian geser langsung terlihat bahwa kenaikan kuat geser oleh tulangan serat disebabkan oleh peningkatan sudut gesek dalam. Sedangkan dari uji tekan bebas, dengan meningkatnya kadar serat kuat tekan bebas tanah yang distabilisasi dengan semen-abu ampas tebu dan tulangan serat meningkat.
\end{abstract}

Kata-kata kunci: Abu ampas tebu, semen, tanah, serat

\section{Pendahuluan}

Teknik-teknik stabilisasi tanah dengan semen sudah banyak diterapkan dengan keberhasilan yang cukup antara lain: peningkatan kuat geser pondasi jalan, perlindungan terhadap lereng, lapisan dasar podasi maupun untuk meningkatkan tahanan terhadap bahaya liquefaction (Kampala, et al., 2013; Hatmoko 2005; 2007). Penerapan stabilisasi tanah dengan semen, abu ampas tebu, abu terbang, abu sekam padi, kombinasi abu terbang + semen, abu ampas tebu + limbah karbit sudah banyak 
dilakukan (Hatmoko et al., 2004, 2005, Diane 2001). Namun demikian penelitian mengenai stabilisasi tanah dengan menggunakan bahan tambah masih berkembang dan selalu dicari bahanbahan tambah untuk kepentingan tersebut. Teknologi perbaikan tanah lempung ekspansif untuk mengurangi kembang-susut dan untuk meningkatkan stabilitas dan kuat geser tanah tersebut sudah banyak dilakukan dan menunjukkan keberhasilannya. Bahan-bahan tambah yang sering digunakan sampai saat ini adalah limbah karbit, semen, aspal, GEOSTA yang difabrikasi dan relatif mahal. Penggunaan bahan - bahan tersebut sudah banyak diterapkan dengan keberhasilan yang cukup antara lain: peningkatan kuat geser pondasi jalan, perlindungan terhadap lereng, lapisan dasar pondasi maupun untuk meningkatkan tahanan terhadap bahaya liquefaction (Maher et al., 1994; Puppala et al. 1995; Hatmoko et al., 2005; 2007).

Jaturapitakkul \& Roongreung (2003), menggunakan campuran limbah kalsium (CCR) karbit dan abu sekam padi sebagai pengganti semen pada mortar, rasio CCR:RHA yang menghasilkan kuat tekan tertinggi adalah 50\% CCR:50RHA yaitu sebesar 15,6 Mpa dengan waktu perawatan 28 hari, dan 19,1 Mpa dengan waktu perawatan 180 hari. Berdasarkan hasil penelitian, material sementasi CCR dan RHA sangat potensial digunakan untuk pembuatan beton yang tidak memerlukan kuat tekan tinggi. Somna et al., 2011 meneliti struktur mikro dari CCR dan ground fly ash (GFA) dengan menggunakan teknik scanning electron microscopy (SEM), X-Ray diffractrometry (XRD) dan Fourier transform infrared (FTIR). Hasil SEM dan XRD dari pasta CCR-GFA dihasilkan calsium silicate hydrate $(\mathrm{CSH})$ dalam bentuk $\mathrm{Ca} 5\left(\mathrm{SiO}_{4}\right)_{2}(\mathrm{OH})_{2}$. Komponen baru ini juga ditemukan dengan analisis FTIR. CSH yang dihasilkan diperoleh dari reaksi $\mathrm{SiO}_{2}$ dari GFA dan $\mathrm{Ca}(\mathrm{OH}) 2$ dari CCR. Reaksi kimianya serupa dengan reaksi pozolanik. Adanya unsur CSH meningkatkan kekuatan tekan pasta. Kekuatan tekan semua sampel meningkat dengan bertambahnya waktu perawatan dan hamper konstan pada umur 42 hari. Makaratat et al., (2010) mengunakan limbah kalsium (CCR) dan fly ash (FA) sebagai bahan ikat pada beton dan meneliti pengaruhnya terhadap sifat mekanik beton. Rasio berat CCR:original fly ash (OF) atau ground fly ash (GF) yang digunakan sebagai bahan ikat pengganti semen adalah 30:70.

Hasil penelitian menunjukan, tanpa menggunakan semen, bahan ikat baru (campuran CCR dan OF atau GF) menghasilkan kuat tekan 28,4 dan 33,5 Mpa pada umur 28 dan 90 hari. Beton dengan menggunakanbahan ikat CCR-OF atau CCR-GF memiliki waktu ikat awal (initial setting time) dan final setting time yang lebih lama dibandingkan dengan beton normal. Campuran limbah CCR dan FA dapat digunakan sebagai bahan ikat baru untuk beton, mengurangi penggunaan produk semen portland dan mengurangi limbah karbit.

Studi tentang penggunaan campuran CCR dan FA untuk memperbaiki kekuatan dari tanah lempung berlanau sudah diteliti oleh (Horpibulsuk et al. 2012). Pengujian struktur mikro mineral menggunaka pengujian SEM dan pengujian kekuatan menggunakan uji tekan bebas. Hasil pengujian menunjukan penambahan CCR menurunkan specific gravity, plastisitas, berat volume kering maksimum dan kadar air optimum pada pengujian pemadatan. Untuk berbagai rasio CCR:FA, kekuatan maksimum diperoleh pada saat kadar air optimum. Perubahan kekuatan dibedakan menjadi tiga zona, yaitu zona aktif, inert dan detoerioration. Pada zona aktif, kekuatan meningkat dengan meningkatnya kandungan CCR untuk semua rasio CCR:FA. Penambahan FA (sebagai pengganti CCR) tidak meningkatkan kekuatan secara signifikan sebab penambahan $\mathrm{Ca}(\mathrm{OH})_{2}$ digunakan oleh material pozalan alami tanah untuk membentuk reaksi pozolanik. Zona aktif dapat ditentukan dengan metode CCR fixation point yang dapat diperoleh dengan pengujian indeks sederhana (pengujian indeks plastisitas). Pada penelitian ini digunakan kadar CCR 7\%. FA sebagai pengganti CCR efektif pada kandungan CCR lebih besar dari kandungan CCR zona aktif, ketika material pozolan alami tidak mencukupi untuk bereaksi dengan $\mathrm{Ca}(\mathrm{OH})_{2}$.

Kampala dan Harpibulsuk, 2013 meneliti sifat teknik dari lempung berlanau yang distabilisasi dengan limbah CCR. Kadar CCR yang diperlukan untuk stabilisasi ditentukan dengan CCR fixation point. CCR fixation point menunjukan kapasitas lempung untuk menyerap ion $\mathrm{Ca} 2+$ dan bereaksi dengan $\mathrm{Ca}(\mathrm{OH})_{2}$. Kadar air optimum digunakan untuk membuat campuran lempung berlanau dan CCR. Kadar air yang lebih kecil dari kadar air optimum tidak mencukupi untuk terjadinya reaksi pozolanik. Tanah yang distabilisasi dengan CCR memiliki kekuatan yang lebih besar dibandingkan dengan yang distabilisasi dengan limbah karbit. Hal ini disebabkan karena CCR mengandung material pozolanik $\left(\mathrm{SiO}_{2}, \mathrm{Al}_{2} \mathrm{O}_{3}\right.$, dan $\left.\mathrm{Fe}_{2} \mathrm{O}_{3}\right)$ sekitar $12,3 \%$. Kuat tekan bebas tanah ekspansif yang distabilisasi dengan abu ampas tebu dan limbah karbit diteliti oleh (Hatmoko et al., 2005). Hasil penelitian menunjukkan bahwa penambahan kaputr menurunkan tekanan dan potensi pengembangan dengan angka yang cukup berarti. Potensi pengembangan turun dari $12 \%$ ke $1,12 \%$, sedangkan tekanan pengembangan turun dari 340 $\mathrm{kPa}$ ke $105 \mathrm{kPa}$, pada tanah dengan kadar limbah 
karbit $10 \%$. Disamping itu, kepadatan maksimum meningkat dan dicapai nilai maksimum pada kadar limbah karbit 4\%. Kuat tekan bebas selalu naik dengan kenaikan prosentase abu ampas tebu. Pada kadar abu ampas tebu $12,5 \%$ dicapai kuat tekan bebas maksimum yang kemudian menurun. Diana et al, (2012) menyajikan hasil penelitian penggunaan abu sekam padi + limbah karbit untuk meningkatkan kuat tekan bebas tanah lempung. Limbah karbit yang digunakan sebesar $8 \%$ dari berat kering tanah. Perbandingan limbah karbit dengan abu sekam padi adalah 30:70; 50:50, dan 70:30\%. Pada berbandingan 50:50 menghasilkan kenaikan kuat tekan bebas 2 kali lipat dari tanah yang tidak distabilisasi. Penelitian serupa dilakukan oleh Diana et al.,(2013) namun besaran yang diukur adalah kuat tarik belah. Komposisi campuran limbah karbit:abu sekam padi 50:50, menghasilkan kuat tarik $84 \%$ lebih tinggi dari pada tanah yang tidak distabilisasi.

Penerapan stabilisasi tanah dengan limbah karbit semen, abu ampas tebu, abu terbang, abu sekam padi, kombinasi abu terbang + semen, abu ampas tebu + limbah karbit sudah banyak dilakukan. (Hatmoko et al., 2004; 2005; 2013, Diane 2001; Diana 2012, 2013; Tahllib et al., 2011; Yadu et al., 2011). Namun demikian, jarang sekali para peneliti yang mengamati pengaruh kombinsi antara AAT dengan limbah karbid/calcium carbid residu(CCR) dalam hubungannya dengan kuat geser tanah ekspansif. Abu ampas tebu (AAT) merupakan limbah pabrik Gula yang merupakan sisa pembakaran tetes tebu yang selama ini tidak dimanfaatkan, jika dibiarkan akan memambah pencemaran lingkungan. AAT sebenarnya mengandung unsur-unsur silika $\left(\mathrm{SiO}_{2}\right)$, alumina $\left(\mathrm{Al}_{2} \mathrm{O}_{3}\right)$, dan ferrit $\left(\mathrm{Fe}_{2} \mathrm{O}_{3}\right)$ yang cukup tinggi jika dibakar pada suhu tertentu, sehingga dapat dimanfaatkan sebagai bahan stabilisasi tanah. Limbah karbid juga merupakan limbah yang mengandung $\mathrm{CaO}$, maupun $\mathrm{Ca}(\mathrm{OH})_{2}$, yang jika dikombinasikan dengan AAT diperkirakan akan membentuk hidrat yang mengakibatkan kuat dan perilaku geser tanah lempung ekspansif akan berubah. Serat geosintetik merupakan bahan dengan kemampuan menahan tegangan tarik cukup tinggi, dibanding dengan tanah, maka dengan inklusi serat ini kedalam tanah ekspansif yang distabilisasi dengan AAT+limbah karbid diharapkan akan meningkatkan kuat geser tanah. Oleh sebab itu, penelitian yang ditulis pada paper ini mengkaji perubahan perilaku fisika dan mekanika tanah (lempung ekspansif) yang distabilisasi dengan AAT dan semen dengan inklusi serat polyester.

\section{Bahan dan Metode}

\section{Bahan penelitian}

Bahan penelitian adalah abu ampas tebu (AAT), semen, serat polyester (S) dan tanah. Abu ampas tebu diambil dari limbah disekitar pabrik gula Madukismo, kabupaten Bantul Daerah Istimewa Yogyakarta. Abu tersebut berupa limbah pembakaran tetes tebu yang banyak dijumpai di sekitar pabrik. Tanah ekspansif diambil dari Wates Kabupaten Kulon Progo. Di lokasi pengambilan sampel, tanah menunjukkan retakretak pada saat kadar air rendah ( kering). Tanah lempung berwarna abu-abu kemerahan jika di pegang terasa sangat halus, dan jika dibasahi tanah tersebut sangat mudah menjadi cair.

\section{Metode}

Pada pengujian geser langsung (ASTM D 3080), sampel-sampel disiapkan pada kondisi kadar air optimum (OMC) dan kepadatan kering maksimu $\mathrm{m}$ (MDD),msehingga pengaruh tulangan serat maupun semen dapat dilihat pada hasil uji tersebut.Hal ini disebabkan oleh terabaikannya pengaruh kadar air dan berat volume. Pengujian geser langsung dilakukan pada sampel lingkaran dengan diameter $63 \mathrm{~mm}$ dan tebal $25,5 \mathrm{~mm}$. Tingkat deformasi z20 $\mathrm{mm} /$ menit. Untuk memperoleh hasil yang baik, setiap komposisi tanah diuji 3(tiga) buah sampel. Tegangan normal pada masing-masing sampel adalah $28.4 \mathrm{kPa}(4 \mathrm{kgr}$ load), $41.2 \mathrm{kPa}$ (8 $\mathrm{kgr}$ load).), and $79.7 \mathrm{kPa}$ (20 kgr). Sementara itu, pengujian kuat tekan bebas menggunakan standard ASTM D 2116. Pengujian ini dilkukan pada sampel silindris : tinggi $(\mathrm{h}=13,65 \mathrm{~cm})$ dan diameter $(\mathrm{d}=6,595 \mathrm{~cm})$. Untuk meyakinkan bahwa kepadatan sampel merata, seluruh bahan yang digunakan pada pengujian dimasukkan kedalam cetakan dan dipadatkan per lapis. Untuk pengujian ini, setiap kombinasi diuji 3(tiga) buah sampel.

\section{Hasil dan Pembahasan}

\section{Pemadatan tanah + semen}

Pada tahap penelitian sebelumnya (penambahan semen pada tanah untuk menurunkan indeks plastisitas), ternyata pada kadar semen $8 \%$ secara optimum menurunkan IP, tekanan pengembangan dan potensi pengembangan (Hatmoko, 2013). Oleh sebab itu pemadatan yang dilakukan didalam penelitian ini hanya 1 buah sampel ( semen $8 \%$ ) dengan masa peram: 0,7, 14, 21, 28 dan 36 hari. Hasil pengujian dapat dilihat pada Tabel 1 . 
Tabel 1. Hasil pengujian kepadatan ringan

\begin{tabular}{ccccccc}
\hline $\begin{array}{c}\text { Masa peram } \\
\text { (hari) }\end{array}$ & $\mathbf{0}$ & $\mathbf{7}$ & $\mathbf{1 4}$ & $\mathbf{2 1}$ & $\mathbf{2 8}$ & $\mathbf{3 6}$ \\
\hline $\begin{array}{c}\text { MDD } \\
\text { (gr/cc) }\end{array}$ & 14,3 & 15,2 & 16,8 & 17,8 & 18,5 & 18,6 \\
$\begin{array}{c}\text { OMC } \\
(\%)\end{array}$ & 36,0 & 34,5 & 33,5 & 33,0 & 32,0 & 31,0 \\
\hline
\end{tabular}

Dengan bertambahnya masa pemeraman, kepadatan maksimum meningkat terus sampai dengan masa pemeraman 28 hari. Dari waktu peram 28 ke 36 hari tidak ada peningkatan yang cukup berarti. Sampai dengan waktu pemeraman 7 hari belum ada peningkatan kepadatan yang cukup berarti disebabkan pada waktu pemeraman tersebut belum terjadi reaksi posolanik. Pada waktu sampai dengan 7 hari tersebut hanya terjadi reaksi pertukaran ion $\mathrm{Ca}^{+2}$ dan $\mathrm{Mg}^{+2}$ yang ada didalam semen dengan ion-ion $\mathrm{K}^{+}$dan $\mathrm{Na}^{+}$yang terkandung didalam tanah. Pada saat itu terjadi butiran-butiran yang lebih besar (flokulasi) yang berakibat pada berubahnya sifat-sifat fisika tanah seperti menurunnya indeks plastisitas (IP) tanah. Kenaikan kepadatan mulai nampak pada masa peram 21 hari yang menunjukkan bahwa pada masa peram tersebut sudah mulai terjadi reaksi posolanik dengan terbentuknya C-S- $\mathrm{H}$ maupun CA-H. Kenaikan kepadatan dari waktu pemeraman 28 hari ke 36 hari tidak cukup brarti. Hal tersebut disebabkan reaksi posolanik yang membentuk kalsium-aluminum-silikat hidrat (C-S-A-H) dimana sifat-sifat mekanika tanah meningkat sudah mengalami kejenuhan. Dari hasil tersebut diperoleh waktu peram optimal 28 hari.

\section{Pemadatan: tanah + semen + abu ampas tebu}

Pengujian pemadatan tanah + semen + abu ampas tebu dilakukan pada kadar semen $8 \%$ dan AAT bervariasi dari, $0,3,6,9$, dan $12 \%$ dengan waktu pemeraman $7,14,21,28$ dan 36 hari, dengan penamaan sampel tanah dapat di lihat pada Tabel 2.

Hasil pengujian tanah $+8 \%$ semen + AAT (0, 3, 6, 9 dan 12\%). Menujukkan kadar air optimum menurun berbanding lurus dengan peningkatan kadar AAT di dalam tanah disebakan oleh sifat AAT yang mampu menyerap air. Peningkatan kepadatan maksimum yang cukup berarti adalah pada kadar AAT 6\% ke 9\%. Dari hasil pengujian ini, diperoleh kadar AAT sebesar $9 \%$.

Tekan bebas : tanah + semen + abu ampas tebu

Kuat tekan bebas dilakukan dengan sampel silindris pada kepadatan kering maksimum (MDD) dan kadar air optimumnya (OMC), dengan kadar semen 8\%, kadar AAT: 0, 3, 6, 9 dan $12 \%$. Ukuran silinder : diameter $6,6 \mathrm{~cm}$, tinggi $13,7 \mathrm{~cm}$. Tanah dipadatkan dengan pemadatan statik. Untuk memperoleh kepadatan yang diharapkan, tanah dimasukkan kedalam silinder kemudian ditekan dalam tiga lapis. Untuk setiap kombinasi diuji dua buah sampel. Hasil pengujian tekan bebas: tanah+8\% semen + AAT dapat dilihat pada Tabel 4

Tabel 2. Simbol sampel untuk uji tekan bebas (semen $=8 \%$ )

\begin{tabular}{cccccc}
\hline $\begin{array}{c}\text { Masa peram } \\
\text { (hari) }\end{array}$ & \multicolumn{5}{c}{ Kadar abu ampas tebu (\%) } \\
\cline { 2 - 6 } & $\mathbf{0}$ & $\mathbf{3}$ & $\mathbf{6}$ & $\mathbf{9}$ & $\mathbf{1 2}$ \\
\hline 0 & $\mathrm{~W}_{0} \mathrm{~T}_{0}$ & $\mathrm{~W}_{0} \mathrm{~T}_{3}$ & $\mathrm{~W}_{0} \mathrm{~T}_{6}$ & $\mathrm{~W}_{0} \mathrm{~T}_{9}$ & $\mathrm{~W}_{0} \mathrm{~T}_{12}$ \\
7 & $\mathrm{~W}_{7} \mathrm{~T}_{0}$ & $\mathrm{~W}_{7} \mathrm{~T}_{3}$ & $\mathrm{~W}_{7} \mathrm{~T}_{6}$ & $\mathrm{~W}_{7} \mathrm{~T}_{9}$ & $\mathrm{~W}_{7} \mathrm{~T}_{12}$ \\
14 & $\mathrm{~W}_{14} \mathrm{~T}_{0}$ & $\mathrm{~W}_{14} \mathrm{~T}_{3}$ & $\mathrm{~W}_{14} \mathrm{~T}_{6}$ & $\mathrm{~W}_{14} \mathrm{~T}_{9}$ & $\mathrm{~W}_{14} \mathrm{~T}_{12}$ \\
21 & $\mathrm{~W}_{21} \mathrm{~T}_{0}$ & $\mathrm{~W}_{21} \mathrm{~T}_{3}$ & $\mathrm{~W}_{21} \mathrm{~T}_{6}$ & $\mathrm{~W}_{21} \mathrm{~T}_{9}$ & $\mathrm{~W}_{21} \mathrm{~T}_{12}$ \\
28 & $\mathrm{~W}_{28} \mathrm{~T}_{0}$ & $\mathrm{~W}_{28} \mathrm{~T}_{3}$ & $\mathrm{~W}_{28} \mathrm{~T}_{6}$ & $\mathrm{~W}_{28} \mathrm{~T}_{9}$ & $\mathrm{~W}_{28} \mathrm{~T}_{12}$ \\
36 & $\mathrm{~W}_{36} \mathrm{~T}_{0}$ & $\mathrm{~W}_{36} \mathrm{~T}_{3}$ & $\mathrm{~W}_{36} \mathrm{~T}_{6}$ & $\mathrm{~W}_{36} \mathrm{~T}_{9}$ & $\mathrm{~W}_{36} \mathrm{~T}_{12}$ \\
\hline
\end{tabular}

Tabel 3. Hasil pemadatan tanah + semen (8\%) + AAT

\begin{tabular}{|c|c|c|c|c|c|c|c|c|c|c|}
\hline \multirow{3}{*}{$\begin{array}{c}\text { Wkt } \\
\text { peram } \\
(\mathrm{hr})\end{array}$} & \multicolumn{10}{|c|}{ Kadar abu ampas tebu (\%) } \\
\hline & \multicolumn{2}{|c|}{$\boldsymbol{0}$} & \multicolumn{2}{|c|}{3} & \multicolumn{2}{|c|}{6} & \multicolumn{2}{|c|}{9} & \multicolumn{2}{|c|}{12} \\
\hline & $\begin{array}{c}\gamma \\
\left(k N / m^{3}\right)\end{array}$ & $\begin{array}{l}\mathbf{w}_{\text {opt }} \\
(\%)\end{array}$ & $\begin{array}{c}\gamma \\
\left(k N / m^{3}\right)\end{array}$ & $\begin{array}{l}\mathbf{w}_{\text {opt }} \\
(\%)\end{array}$ & $\begin{array}{c}\gamma \\
\left(k N / m^{3}\right)\end{array}$ & $\begin{array}{l}\mathbf{w}_{\text {opt }} \\
(\%)\end{array}$ & $\begin{array}{c}\gamma \\
\left(k N / m^{3}\right)\end{array}$ & $\begin{array}{l}\mathbf{W}_{\text {opt }} \\
(\%)\end{array}$ & $\begin{array}{c}\gamma \\
\left(k N / m^{3}\right)\end{array}$ & $\begin{array}{l}\mathbf{w}_{\text {opt }} \\
(\%)\end{array}$ \\
\hline 0 & 14,3 & 36 & 14,8 & 35 & 15,0 & 34,0 & 15,4 & 33,0 & 15,5 & 36,0 \\
\hline 7 & 15,2 & 34,5 & 15,9 & 34 & 15,6 & 33,5 & 15,9 & 32,0 & 15,9 & 34,5 \\
\hline 14 & 16,8 & 33,5 & 16,9 & 33 & 17,1 & 33,0 & 17,3 & 31,5 & 17,3 & 33,5 \\
\hline 36 & 18,6 & 31,0 & 18,9 & 30 & 18,9 & 30,5 & 19,2 & 29,0 & 19,3 & 31,0 \\
\hline
\end{tabular}


Tabel 4. Hasil pengujian tekan bebas $(\mathrm{kPa})$ : tanah + $8 \%$ semen + AAT

\begin{tabular}{cccrrr}
\hline $\begin{array}{c}\text { Waktu } \\
\text { peram } \\
\text { (hari) }\end{array}$ & \multicolumn{5}{c}{ Prosentase abu ampas tebu ( AAT) : \% } \\
\cline { 2 - 6 } & \multicolumn{1}{c}{$\mathbf{0}$} & \multicolumn{1}{c}{$\mathbf{6}$} & \multicolumn{1}{c}{$\boldsymbol{9}$} & \multicolumn{1}{c}{$\mathbf{1 2}$} \\
\hline 0 & 40,2 & 40,9 & 41,0 & 41,8 & 42,1 \\
7 & 41,2 & 58,5 & 65,3 & 75,1 & 76,0 \\
14 & 45,3 & 98,2 & 108,8 & 125,9 & 129,6 \\
21 & 52,6 & 156,1 & 170,4 & 227,8 & 235,2 \\
28 & 72,1 & 245,6 & 304,5 & 337,9 & 345,9 \\
36 & 74,2 & 250,0 & 310,8 & 354,7 & 368,0
\end{tabular}

Pada kadar AAT 0\% ( tanah + semen 8\%) ada kenaikan kuat tekan bebas tehadap waktu pemeraman, namun kenaikan tersebut tidak cukup berarti. Kenaikan kuat tekan bebas cukup berarti terjadi pada tanah $+8 \%$ semen $+9 \%$ AAT. Pada kombinasi tersebut, kuat tekan bebas sebesar 41.8 kPA pada masa peram 0 hari, meningkat menjadi $354,7 \mathrm{kPa}$ pada masa peram 36 hari. Hal yang mirip terjadi pada jadar AAT $12 \%$, namun kenaikan kuat tekan bebas dari AAT 9\% ke 12\% tidak cukup berarti, dibanding kenaikan dari 6 ke $9 \%$. Kenaikan kuat tekan bebas rerata dari $9 \%$ AAT ke $12 \%$ AAT sekitar: 2,9\%; sedangkan rerata kenaikan kuat tekan bebas dari kadar AAT 6\% ke $9 \%$ sekita $16,3 \%$. Terhadap waktu pemeraman, kenaikan kuat tekan bebas yang sangat berarti terjadi dari masa peram 21 hari ke masa pemeraman 28 hari, kemudian menjadi datar dari masa peram 28 hari ke 36 hari. Rerata kenaikan kuat tekan bebas dari 21 ke 28 hari sekitar 55,1\%, dibanding 3,9\% dari 28 hari ke 36 hari.

Uji pemadatan standard: tanah $+\operatorname{semen}(8 \%)+$ AAT $(9 \%)+$ Serat

Uji pemadatan standar pada tanah + semen $(8 \%)+$ AAT $(9 \%)$ sudah dilakukan sebelumnya di dalam penelitian ini dengan hasil MDD = 18,9 $\mathrm{kN} / \mathrm{m}^{3}$ dan $\mathrm{OMC}=30 \%$. Pada penelitan lanjutan ini akan dilakukan pada : tanah + semen + AAT dengan inklusi serat Polyester ( 2 dan 4\%) dengan orientasi bebas. Variasi kadar air adalah: 10, 15, 20, 25, 30, dan 35\%. Hasil pengujian kepadatan dapat dilihat pada Tabel 5.

Tabel 5. Hasil uji pemadatan: tanah + semen + AAT + serat

\begin{tabular}{cccc}
\hline \multirow{2}{*}{$\begin{array}{c}\text { Kadar air } \\
(\%)\end{array}$} & \multicolumn{3}{c}{ Kepadatan $\left(\mathbf{k N} / \mathbf{m}^{3}\right)$} \\
\cline { 2 - 4 } & $\mathrm{C}_{8} \mathrm{~A}_{9}$ & $\mathrm{C}_{8} \mathrm{~A}_{9} \mathrm{~S}_{2}$ & $\mathrm{C}_{8} \mathrm{~A}_{9} \mathrm{~S}_{4}$ \\
\hline 10 & 13,6 & 14,0 & 15,0 \\
15 & 16,0 & 16,5 & 17,0 \\
20 & 16,5 & 17,0 & 17,4 \\
25 & 17,4 & 18,0 & 20,1 \\
30 & 18,5 & 19,0 & 19,4 \\
35 & 17,6 & 17,9 & 18,2 \\
\hline
\end{tabular}

Catatan : $\mathrm{C}_{\mathrm{x}} \mathrm{A}_{\mathrm{y}} \mathrm{S}_{\mathrm{z}}$ : tanah dgn semen $\mathrm{x} \%$, AAT y\%, serat $\mathrm{z} \%$
Hasil menunjukkan bahwa kepadatan kering maksimum (MDD) mengalami kenaikan dengan bertambahnya kadar serat, sedangkan kadar air optimum (OMC) turun dengan meningkatnya kadar serat, lihat Tabel 6.

Tabel 6. MDD dan OMC tanah + semen +AAT + serat

\begin{tabular}{lll}
\hline \multirow{2}{*}{ C8A9 } & $M D D(k N / m 3)$ & 18.5 \\
& $O M C(\%)$ & 30,0 \\
\hline \multirow{2}{*}{ C8A9S2 } & $M D D(k N / m 3)$ & 18,9 \\
& $O M C(\%)$ & 29,2 \\
\hline \multirow{2}{*}{ C8A9S4 } & $M D D(k N / m 3)$ & 19,6 \\
& $O M C(\%)$ & 28,6 \\
\hline
\end{tabular}

Temuan ini berbeda dengan hasil penelitian yang disampaikan oleh Setty dan Rao (1997). Pada penelitian mereka menunjukkan bahwa MDD dan OMC mengalami kenaikan oleh bertambahnya kadar serat pada tanah kelanauan dengan inklusi serat polyopropeline. Hasil tersebut mengindikasikan bahwa serat polypropeline mampu menyerap air sehingga OMC meningkat. Pengaruh serat geosintetik terhadap MDD pada penelitian ini tidak cukup signifikans, oleh sebab itu perlu penelitian lanjutan dengan memberikan variasi serat yang lebih banyak, tidak hanya $2 \%$ dan $4 \%$.

\section{Uji geser langsung: tanah $+8 \%$ semen $+9 \%$ AAT + serat}

Pada pengujian kepadatan menunjukkan bahwa tidak banyak pengaruh yang cukup berarti terhadap MDD tanah + semen yang sama pada pengujian pemadatan. Pengujian geser langsung untuk tanah + semen $(8 \%)+$ AAT $(9 \%)$ dilakukan terpisah dengan komposisi yang sama dengan inklusi $2 \%$ dan $4 \%$ tulangan serat polyester, sehingga pengaruh inklusi serat dapat dilihat secara lansung dari hasil pengujian.

Uji geser langsung menggunakan sampel lingkaran dengan : $d=6,30 \mathrm{~cm}$, tebal $2,55 \mathrm{~cm}$, luas sampel $31,17 \mathrm{~cm}^{2}$ dengan tingkat penurunan 0,25 $\mathrm{mm} / \mathrm{menit}$. Setiap kombinasi di buat tiga buah sampel, dengan tegangan normal: $(8,843 / 31,17=$ $\left.0,284 \mathrm{~kg} / \mathrm{cm}^{2}(28,4 \mathrm{kPa})\right),(12,843 / 31,17=0,412$ $\mathrm{kg} / \mathrm{cm}^{2}(41,2 \mathrm{kPa})$, dan $(16,843 / 31,17=0,540$ $\mathrm{kg} / \mathrm{cm}^{2}(54 \mathrm{kPa})$. Hubungan antara tegangan geser dan perubahan lateral dapat di lihat pada Gambar 1

Sedangkan hubungan antara perubahan vertikal dan perubahan lateral dapat dilihat pada Gambar 2.

Hubungan antara tegangan geser - perubahan lateral serta perilaku perubahan volume pada tanah + semen + AAT sangat dipengaruhi oleh inklusi 
serat polyester. Daktilitas tanah yang distabilisasi tersebut meningkat dengan meningkatnya prosentase serat. Hal tersebut ditunjukkan oleh keruntuhan tanah dimana tanah + semen + AAT tanpa inklusi serat polyester mengalami keruntuhan pada perubahan horisontal kurang lebih $2 \mathrm{~mm}$, sementara tanah dengan tulangan dapat mencapai $4 \mathrm{~mm}$ dan bahkan lebih untuk tegangan niormal yang lebih tinggi.

Dari hubungan antara perubahan vertikal dengan horisontal terlihat bahwa semakin besar prosentase serat perubahan vertikal semakin tinggi. Perubahan vertikal maksimum pada tanah tanpa tulangan antara 0,25 sampai dengan 0,35 mm, sementara pada tanah dengan tulangan antara 0,45 sampai $0,70 \mathrm{~mm}$. Perubahan vertikal tersebut meningkat dengan meningkatnya tegangan normal. Hubungan antara tegangan geser dan parameter kuat geser tanah (c dan $\varphi$ ) yang diperoleh dari pengujian geser langsung dapat dilihat pada Gambar 3. Dari hasil tersebut terlihat bahwa perubahan $\mathrm{c}$ dan $\varphi$ akibat penambahan serat kelihatan konsisten, dengan meningkatnya prosentase serat kohesi, c, tidak banyak meningkat sedangkan sudut gesek dalam $(\varphi)$ mengalami peningkatan yang relatif besar. Oleh sebab itu, secara umum kuat geser tanah dengan tulangan mengalami peningkatan.

Tabel 7. Hasil uji Geser Langsung : c dan $\varphi$

\begin{tabular}{lrrr}
\hline Parameter geser & $\mathbf{C}_{\mathbf{8}} \mathbf{A}_{\mathbf{9}} \mathbf{S}_{\mathbf{0}}$ & $\mathbf{C}_{\mathbf{8}} \mathbf{A}_{\mathbf{9}} \mathbf{S}_{\mathbf{2}}$ & $\mathbf{C}_{\mathbf{8}} \mathbf{A}_{\mathbf{9}} \mathbf{S}_{\mathbf{4}}$ \\
\hline Kohesi, c (kPa) & 32,15 & 35,50 & 39,40 \\
$\begin{array}{l}\text { Sudut gesek dalam } \\
, \varphi\left({ }^{\circ}\right)\end{array}$ & 21,20 & 25,90 & 27,80 \\
\hline
\end{tabular}

Tegangan Geser vs. Perubahan Horisontal

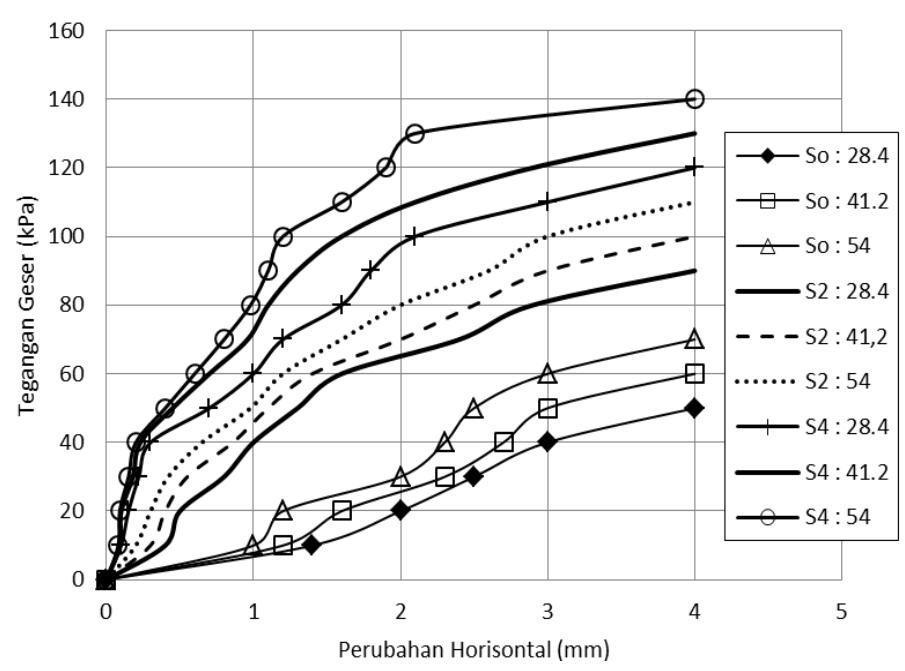

Gambar 1. Hubungan antara tegangan geser dengan perubahan lateral

Perubahan Vertikal vs Perubahan Horisontal

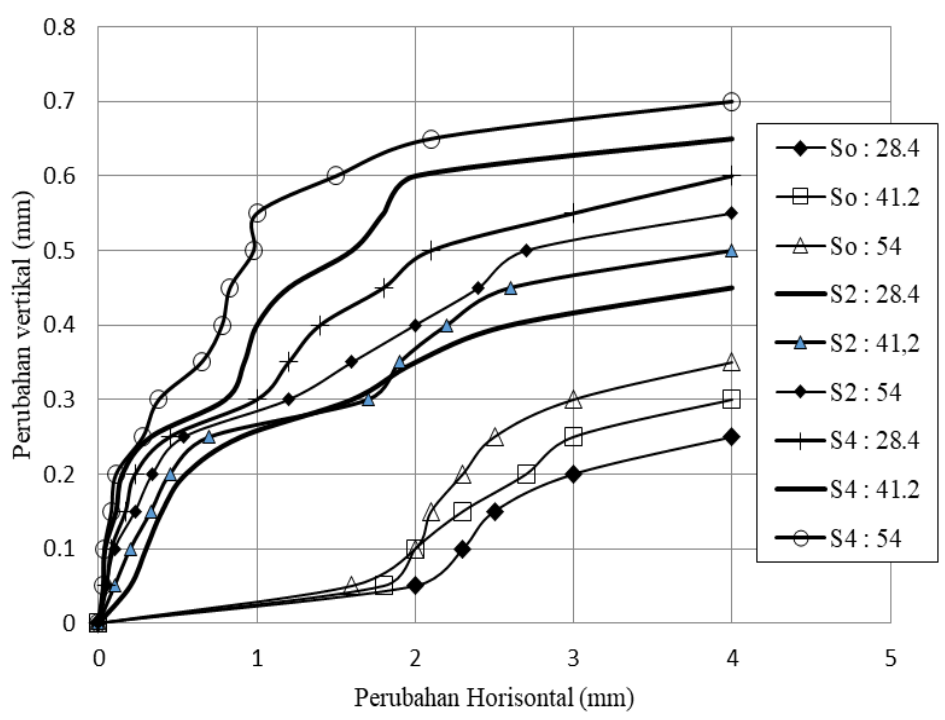

Gambar 2. Hubungan antara perubahan vertikal dengan perubahan lateral 
Tegangan Geser vs Tegangan Nrmal

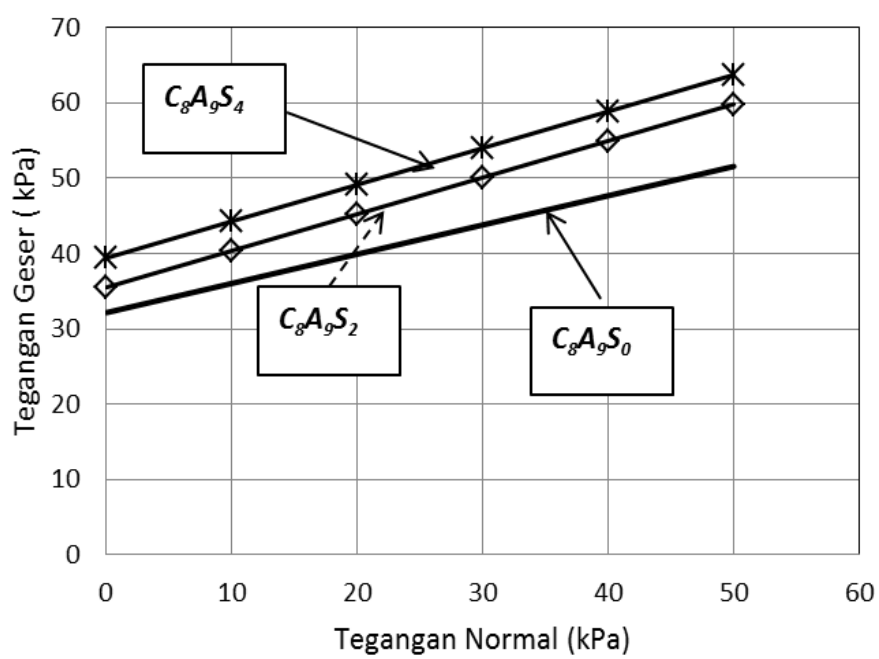

Gambar 3. Hasul uji geser langsung Tanah + semen + AAT + serat polyester

Hubungan Tegangan-Regangan Uji Tekan Bebas

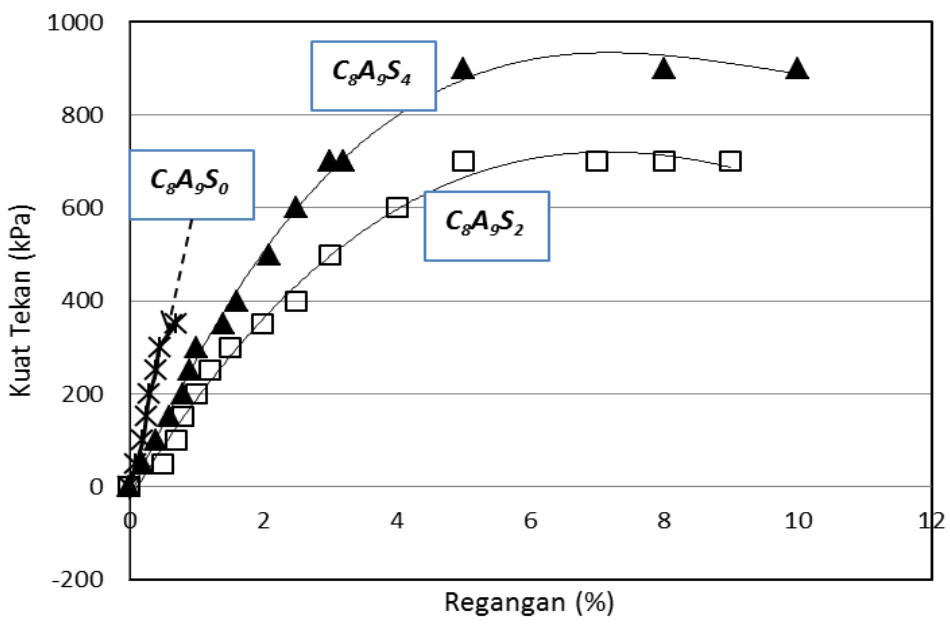

Gambar 4. Hasil Uji Tekan Bebas : Kuat tekan vs. regangan aksial

Perlu diketahui bahwa derajat kejenuhan sampel tanah + semen + AAT + Serat pada kondisi MDD-OMC cukup tinggi, melampaui $70 \%$. Pengembangan pada tanah sampel tak jenuh pada kondisi tingkat deformasi yang cukup cepat akan menghasilkan tekanan air pori negatif pada pengujian geser langsung tersebut. Disamping itu, panjang serat kemungkinan melebihi ketebalan sampel akan berakibat tertekuknya serat polyester secara berulang di dalam alat geser langsung. Kekurangan tersebut perlu dipertimbangkan pada saat melakukan evaluasi terhadap kuat geser tanah + semen + AAT + Serat.

Uji Tekan bebas : tanah $+\operatorname{semen}(8 \%)+$ AAT $(9 \%)+$ Serat

Hampir sama dengan uji tekan bebas pada tanah + semen + AAT, uji kuat tekan bebas dilakukan dengan sampel silindris pada kepadatan kering maksimum (MDD) dan kadar air optimumnya (OMC), dengan kadar semen 8\%, kadar AAT 9\%, dengan tulangan serat polyester 2 dan $4 \%$. Kemudian penamaan sampel adalah: $\mathrm{C}_{8} \mathrm{~A}_{9} \mathrm{~S}_{0}$ (Tanah $+8 \%$ semen $+9 \%$ AAT - tanpa tulangan), $\mathrm{C}_{8} \mathrm{~A}_{9} \mathrm{~S}_{2}$ (Tanah $+8 \%$ semen $+9 \%$ AAT - dengan $2 \%$ tulangan), dan $\mathrm{C}_{8} \mathrm{~A}_{9} \mathrm{~S}_{4}$ (Tanah $+8 \%$ semen $+9 \%$ AAT - dengan $4 \%$ tulangan). Masa pemeraman diambil 28 hari dengan kuat tekan bebas $\mathrm{C}_{8} \mathrm{~A}_{9} \mathrm{~S}_{0}$ sebesar $337,9 \mathrm{kPa}$ (uji tekan bebas sebelumnya). Ukuran silinder : diameter $6,6 \mathrm{~cm}$, tinggi $13,7 \mathrm{~cm}$. Tanah dipadatkan dengan pemadatan statik. Untuk memperoleh kepadatan yang diharapkan, tanah dimasukkan kedalam silinder kemudian ditekan dalam tiga lapis. Hasil uji tekan bebas dapat dilihat pada Gambar 4. Dari hasil tersebut, terlihat bahwa kuat tekan bebas 
tanah meningkat dengan meningkatnya kandeungan serat.

\section{Kesimpulan}

Serangkaian pengujian laboratorium telah dilakukan untuk mengkaji pengaruh abu ampas tebu, limbah karbit dan serat polyester terhadap perilaku geser tanah. Pembahasan terhadap hasil pengujian tersebut juga sudah dilakukan, maka kesimpulan dari studi tersebut. Pertama uji pemadatan tanah + semen menunjukkan bahwa dengan bertambahnya masa pemeraman, kepadatan maksimum meningkat terus sampai dengan masa pemeraman 28 hari. Dari waktu peram 28 ke 36 hari tidak ada peningkatan yang cukup siginifikans.kemudian uji pemadatan tanah + semen + AAT menunjukkan bahwa kadar air optimum menurun berbanding lurus dengan peningkatan kadar AAT di dalam tanah. Sedangkan kepadatan meningkat dan mencapai harga pada kadar AAT 6\% ke 9\%.

Pada pengujian tekan bebas: tanah + semen + AAT menunjukkan kenaikan kuat tekan bebas yang cukup signifikans terjadi pada tanah $+8 \%$ semen $+9 \%$ AAT. Pada kombinasi tersebut, kuat tekan bebas sebesar 41,8 kPA pada masa peram 0 hari, meningkat menjadi $354,7 \mathrm{kPa}$ pada masa peram 36 hari. Hal yang mirip terjadi pada jadar AAT $12 \%$, namun kenaikan kuat tekan bebas dari AAT $9 \%$ ke $12 \%$ tidak cukup signifikans, dibanding kenaikan dari 6 ke 9\%. Terhadap waktu pemeraman, kenaikan kuat tekan bebas secara signifikans terjadi dari masa peram 21 hari ke masa pemeraman 28 hari, kemudian menjadi datar dari masa peram 28 hari ke 36 hari.

Pengujian pemadatan tanah + semen + AAT + serat diperoleh bahwa kepadatan kering maksimum (MDD) mengalami kenaikan dengan bertambahnya kadar serat, sedangkan kadar air optimum (OMC) turun dengan meningkatnya kadar serat. Dari hubungan antara tegangan geser dengan deformasi lateral pada pengujian geser langsung tanah + semen + AAT + serat, menunjukan bahwa daktilitas tanah meningkat dengan meningkatnya prosentase serat. Dari hubungan antara perubahan vertikal dengan horisontal terlihat bahwa semakin besar prosentase serat perubahan vertikal semakin tinggi. Perubahan vertikal maksimum pada tanah tanpa tulangan antara 0,25 sampai dengan 0,35 $\mathrm{mm}$, sementara pada tanah dengan tulangan antara 0,45 sampai 0,70 mm. Dari hasil uji geser langsung terlihat bahwa perubahan $\mathrm{c}$ dan $\varphi$ akibat penambahan serat kelihatan konsisten, dengan meningkatnya prosentase serat kohesi, c, tidak banyak meningkat sedangkan sudut gesek dalam $(\varphi)$ mengalami peningkatan yang relatif besar. Secara umum kuat geser tanah dengan tulangan mengalami peningkatan.

\section{Ucapan Terimakasih}

Ucapan terima kasih peneliti disampaikan kepada Direktorat Jenderal Penguatan Riset dan Pengembangan, Kementerian Riset, Teknologi dan Pendidikan Tinggi Republik Indonesia atas dukungan dana melalui pendanaan hibah Penelitian Produk Terapan serta Universitas Atma Jaya Yogyakarta atas semua dukungan yang diberikan pada penelitian ini. Peneliti juga mengucapkan banyak terima kasih kepada P.G. Madukismo, Bantul DIY atas ijinnya untuk mengambil abu ampas tebu sebagai bahan pokok pada penelitian ini.

\section{Daftar Pustaka}

Diane, A. (2001). Studi Pengaruh Penambahan Abu Sekam Padi Terhadap Kuat Geser, Potensi Pengembangan, danNilai CBR Tanah Lempung, Tugas Akhir Sarjana Strata I, Pro-Di. Teknik Sipil Universitas Atma Jaya, Yogyakarta.

Diana, W, Muntohar, A.S. (2012). Kuat Tekan Bebas Tanah Lempung yang Distabilissi dengan Semen dan Abu Sekam Padi. Prosiding Konferensi Nasional Teknik Sipil ke 6 (hal. 3337), Universitas Trisakti, Jakarta.

Diana, W, Muntohar, A.S (2013) ,Kuat Geser dan Kuat Tarik Belah Tanah Lempung yang Distabilisasi dengan Semen dan Abu Sekam Padi. Prosiding Konferensi Nasional Teknik Sipil ke 7(hal.69-75), Universitas Sebelas Maret, Surakarta.

Hatmoko, John., T. \& Lulie, Y. (2004). UCS Tanah Lempung Ekspansif yang di Stabilisasi dengan Abu Ampas Tebu dan Semen, Laporan Penelitian Universitas Atma Jaya, Yogyakarta.

Hatmoko, J.T \& Suryadharma, H.Y. (2005). Studi liquefaction di DIY Bagian Utara, Laporan Studi LPPM Universitas Atma Jaya, Yogyakarta.

Hatmoko,J.T \& Suryadharma,H.Y. (2007). Perbaikan\Gradasi Tanah untuk Meningkatkan ketahanan Terhadapliquefaction, Laporan Studi LPPM Universitas Atma Jaya, Yogyakarta.

Hatmoko, J.T \& Suryadharma, H.Y. (2013). Perbaikan Tanah Ekspansif dengan Abu Sekam Padi dan Semen, Laporan Studi LPPM Universitas Atma Jaya, Yogyakarta. 
Horpibulsuk, S, \& Miura, N 2001 ,A new approach for studying of behavior of cement stabilized clay, Proceeding the $15^{\text {th }}$ International Confrence on soil mechanics and geotechnical engineering Istanbul,Turkey, 3, 1759-1762.

Horpibulsuk, S., Phetchuay, C., \& Chinkulkijniwat, A. (2011). Soil stabilization by calcium carbide residue and fly ash. Journal of materials in civil engineering, 24(2), 184-193.

Horpibulsuk,S. (2013). Engineering properties of silty clay stabilized with calcium carbid residu , Journal of materials in Civil Engineering, ASCE, 125(5), $470-475$.

Jaturapitakkul, C., \& Roongreung, B. (2003). Cementing material from calcium carbide residuerice husk ash. Journal of Materials in Civil Engineering, 15(5), 470-475.

Kampala, A., \& Horpibulsuk, S. (2013). Engineering properties of silty clay stabilized with calcium carbide residue. Journal of Materials in Civil Engineering, 25(5), 632-644.

Kasama, K., Ochiai, H., \& Yasufuku, N. (2000). On the stress-strain behaviour of lightly cemented clay based on an extended critical state concept. Soils and Foundations, 40(5), 37-47.

Li Y, Hu Y, Hu ,C. (2008), Microstructures and mechanical properties of natural fibres, Advanced Materials Research, 33-37, 553-558.

Maher, M. H., \& Ho, Y. C. (1994). Mechanical Properties of Kaolinite / Fiber Soil Composite. Journal of Geotechnical Engineering, 120(8), 1381-1393.
Makaratat, N, Jaturapitakkul, C, \& Laosamathikul, T. (2010). Effect of Calsium Carbide Residue -Fly Ash Binder on Mechanical Properties of Concrete, Journal of materials in Civil Engineering ASCE 22(11)., 1164-1170.

Mittal, D. (1997). Silica from Ash: A Valuable Product from Waste Material, Resonance, 2(7), hal. 64-66.

Puppala, A. J., Acar, Y. B., \& Tumay, M. T. (1995). Cone penetration in very weakly cemented sand. Journal of Geotechnical Engineering, 121(8), 589-600.

Setty, K.R.N.S, and Rao,S.V.G. (1997). Characteristics of fibre-reinforced lateritic soils, Proceedings of Indian Geotechnical Conference, 1, 329 - 333

Thalib, M, Bankole, G.M. (2011). Improvement of index properties and compaction characteristics of lime stabilized tropical lateritic clays with risk husk admixture, Journal of Geotechnicaland Geoenvironmental Engineering, Vol 16, pp. 983 996.

Vatsala, A. (2001). Elastoplastic Model for Cemented Soils, Journal of Geotechnical and Geoenvironmental Engineering, 127(8), 679-687.

Wong, I. H., \& Poh, T. Y. (2000). Effects of jet grouting on adjacent ground and structures. Journal of Geotechnical and Geoenvironmental Engineering, 126(3), 247-256.

Yadu, L., Tripathi, R. K., \& Singh, D. (2011). Comparison of fly ash and rice husk ash stabilized black cotton soil. International Journal of Earth Sciences and Engineering, 4(06), 42-45. 